\title{
FROM URBAN-INDUSTRIAL ECONOMY TO METROPOLITAN-FINANCIAL ECONOMY
}

\author{
da economia urbano-industrial à economia metropolitano-financeira \\ Eudes Leopoldo *
}

\begin{abstract}
Resumo
O primado da dimensão metropolitana simultânea à dominação da esfera financeira revoluciona o espaço social e determina novas formas e conteúdos à sociedade. Assim, há um novo processo de organização produtiva e regional: a economia metropolitano-financeira. Diante dessa hipótese, o espaço em transição põe o imperativo da renovação, negação e superação das categorias e conceitos: da cidade à metrópole, da urbanização à metropolização, do industrial ao financeiro, da forma urbana à forma metropolitana. Verifica-se que a forma metropolitana diz respeito à rede, integração e conexão, que nega e reafirma a aglomeração, reunião e encontro, iluminando novas simultaneidades, que não apagam as anteriores, mas as confrontam, convergem-se. A Geografia urbana necessita avançar no campo teórico e prático da metropolização e financeirização do mundo, em busca das novas determinações do espaço postas pela época metropolitano-financeira em desenvolvimento.
\end{abstract}

Palavras-chave: Época metropolitano-financeira; Metropolização do Espaço; Rede; Conexão; Integração.

\begin{abstract}
The primacy of the metropolitan dimension simultaneously to the domination of the financial sphere revolutionizes social space and determines new forms and content to society. Thus, there is a new process of production and regional organization: the metropolitan-financial economy. Given this hypothesis, the space in transition places the imperative on renewal, denial and overcoming categories and concepts: from the city to the metropolis, from urbanization to metropolization, from industrial to financial, from the urban form to the metropolitan form. It is verified that the metropolitan form concerns the network, integration and connection; it denies and reaffirms agglomeration, gathering and meeting, shining light on new simultaneities, which do not erase previous forms, but face them, to converge. Urban Geography needs to advance in the theoretical and practical field of the metropolization and financialization of the world, in search of the new determinations of space posed by the metropolitan-financial era under development.
\end{abstract}

Key words: Metropolitan-financial era; Metropolization of Space; Network; Connection; Integration.

\section{Resumen}

A primacía de la dimensión metropolitana simultánea a la dominación de la esfera financiera revoluciona el espacio social e impone nuevas formas y contenidos para la sociedad. Por lo tanto, hay un nuevo proceso de organización productiva y regional: la economía metropolitano-financiera. Dada esta hipótesis, el espacio en transición pone el imperativo de la renovación, negación y superación de categorías y conceptos: de la ciudad a la metrópolis, de la urbanización a la metropolización, del industrial al financiero, de la forma urbana a la forma metropolitana. En esta dirección, la forma metropolitana se relaciona a la red, integración y conexión, que niega y reafirma la aglomeración, reunión y encuentro, iluminando nuevas simultaneidades, que no borran las anteriores, pero confrontan-las, convergen-se. Geografía urbana necesita avanzar en el campo teórico y práctico de la metropolización y financiarización del mundo en busca de las nuevas determinaciones del espacio planteadas por el desarrollo de la época metropolitano-financiera.

Palabras clave: Época metropolitano-financiera; Metropolización del espacio; Red; Conexión; Integración.

(*) Phd Student State University of São Paulo (Universidade Estadual de São Paulo) - Avenida Prof. Lineu Prestes, 338, CEP: 05508080 - São Paulo, (SP), Brasil. Tel: (+55 11) 30913769 - eudesleopoldos@gmail.com 


\section{INTRODUCTION}

Never before in global geography and history has the sensation of having the world in the palm of ones hand been so strong. Technological advances in the fields of information and transport systems, as well as the real promises of hypersensitive connections between individuals (brain-brain interface, neurological chips), automation of the environment (internet of things) and new everyday experiences (the artificial sixth sense, futuristic glasses integrated with the internet), lead mankind to a new composition of spatial simultaneity.

Today, what David Harvey (1989) called "space-time compression" and Milton Santos ([1996] 2000), later called "the convergence of moments" is the foundation of the new relationship between society and space, which establishes the "form of simultaneity" referred to by Henri Lefebvre ([1968] 2001), with more intensity and depth than for half a century. The annihilation of the classical urban hierarchy and the intensification of exchanges within and between the networks of cities and centralities by the "implosion-explosion of the metropolis" (LEOPOLDO, 2013a) reveals and points to space in transition. This scenario determines the metropolitan condition as the present (historical present time) and the "horizon" (limit and possibility) of a new production of space, establishing a network, a connection and integration as second-degree spatial forms.

The urbanization of society has advanced on all the the latitudes and longitudes of the planet and opened the way for the concrete emergence of the metropolization of space. Metropolitan conceptions of urban and regional planning (New York and London in the middle of the last century), the spatial policies of the metropolitan deconcentration of space and the development of metropolises (France and Brazil in the 1960s and 1970s), the construction of artificial islands (Dubai in the United Arab Emirates, Miami and Balboa in the United States, Bahrain, Qatar, Kuwait), the Chinese ghost cities (Tianducheng, Zhengdong New Area, Kangbashi New Area), the bankruptcy of American cities (Detroit, San Bernardino, Orange County, Harrisburg) and the fever of gated communities and planned neighborhoods show that the production of urban space alone is not enough for the new strategies of capital accumulation.

A new moment in the production of space needed to be born to allow the acceleration of "capital turnover time" and the promotion, updating and renewal of urbanization. Thus, metropolization emerges as an endless source of the modernization of the capitalist mode of production, allowing an increase in the scope of control of territory and the formation of a new policy of space. Metropolization is the "expanded reproduction of the metropolis" (LEOPOLDO, 2013a), the colonization of urbanization. So, in the twenty-first century there is a double- strength consolidation of the power of cities and their metropolitan areas. In this way, a metropolitan form emerges (network, integration, connection), which denies, but does not erase, the urban form (agglomeration, gathering, meeting).

The marks, signs and unfolding of the metropolitan are everywhere. "Closed condominiums, shopping malls, metropolitan transport networks, business condominiums, planned neighborhoods, hypermarkets, gated communities and others mark the materiality of the political economy of metropolization" (LEOPOLDO, 2014a, p. 84). We begin with the idea that metropolization involves on the one hand, the centralization of capital in major metropolitan centers and on the other, the dissemination of metropolitan content beyond metropolises and their metropolitan areas.

The change of orientation of the production of space (from urbanization to metropolization) is directly linked to the new spectra of the predominant process of world capitalism: the financialization of the economy. The thesis presented herein is that the world has moved from an urban-industrial economy to a metropolitan-financial economy, establishing a new era (LEOPOLDO, 2014a and 2014b). This is the metropolitan-financial era.

In the face of the new challenges of the modern world, new concepts and issues are imposed on Urban Geography. Thus, geographical thinking about the city and the urban is invited to update itself, seeking to capture the space in transition and its new determinations. Empirical studies of Urban Geography, which have become a tradition in this specialized line of thought, need to walk 
alongside theoretical renewal, otherwise we will be doomed to be mere replicators of ideas. With a view to provoking a debate in Urban Geography and beyond, we have conducted the exercise of understanding the universal and the difference of the contemporary world, based on practical research and critical approaches.

\section{FROM THE URBAN-INDUSTRIAL ECONOMY TO THE METROPOLITAN-FINANCIAL ECONOMY}

Henri Lefebvre (1972), in his book The Urban Revolution, uses historical periodization to speak about the emergence of "urban society", which illuminates a new world of contradictions. There would be three converging, contrasting, and juxtaposed periods: the agrarian age, the industrial age and the urban age. According to Lefebvre (1972), the urban constitutes itself, insofar as it is discovered and revealed, becoming both real and virtual, with the concrete and Utopian predominance of the gathering and the meeting.

In the book The Postmodern Condition, David Harvey (1989) embarks on a geo-economic conception of transition, with a heuristic base on the school of regulation. According to the eminent geographer, the twentieth century saw the transition from Fordism to flexible accumulation, a path with intense metamorphoses in lifestyle, organization of work, and the state-market relationship. Harvey notes the "space-time compression" as a determination of the contemporary world, which challenges the experiences of everyday life.

In turn, Milton Santos ([1996] 2000), in The Nature of Space, periodizes geography and history from the triad: the natural environment, the technical environment, and the technical-scientific-informational environment. The empire of the new, increasingly technical, scientific and informational social variables has transformed the space-time, since the earliest times, when mankind still had some relationship of subordination to nature. For the Brazilian geographer, the key link is technical, which is the main form of relationship between man and nature, society and the environment.

These historical and geographical concepts of universal chronology and choreography ratify a radical transformation of capitalism in the second half of the twentieth century. One way or another, there are advances in the understanding of the predominant moments of social space-time. However, in view of our times, we point to the need to propose a new form of knowledge of the periodization of world history and geography, from the predominance of the following production times: agrarian-commercial economy, urban-industrial economy, metropolitan-financial economy. Each makes up a specific time, emerging from a radical break with the preceding one, keeping continuities and marks.

In the official literature there is a recurrent perspective of a transition from an agrarian-commercial economy to an urban-industrial economy. However, the transition from the urban-industrial economy to a new time, the metropolitan-financial economy, has not deserved a more detailed treatment. There is not a more comprehensive understanding of the terms of what we are calling the metropolitan-financial economy. According to the interpretations, it seems that we still live under the dominance of the urban-industrial economy, even if the new forms and contents of the processes under development, elucidated by these same readings, point to a new space-time configuration, a new simultaneity.

The metropolitan-financial economy is a new capitalist frontier, a new moment articulated and converging the agrarian-commercial economy and urban-industrial economy. It dominates, but retains traces, processes and contradictions linked to the preceding economies. Each of these economies determines the means of their respective societies and mobilizes spaces and times of its historical and geographical present. Each economy can only be resolved with and within its own space.

Space is the simultaneity of social relations of production. It is not merely land where history takes place. It is actual history in movement. As each economy requires a space and time, illuminating specific production and reproduction processes, we can talk about periods, eras, times, and 
moments that are not thought of as partitioned and separate stages. Each period converses with its predecessor and its posterity.

The agrarian-commercial economy determined an epoch. In fact, capitalism consolidated itself with commercial exchanges. In this movement, the exchange of agricultural products and precious metals overseas allowed the consolidation of European centers of accumulation and the intense exploitation of labor in the American, African and Asian colonies. In this dynamic, cities were established as places for agricultural surplus and administrative and commercial centers. According to Marx ([1867] 1985), capital began its true saga at that time, in the sixteenth century, with profound changes in economic structures and the emergence of capitalism.

The agrarian-commercial era was strongly linked to the subordinate incorporation of a new continent to the capitalist logic: Latin America. In the words of Quijano (2005, p. 9) "Latin America was both the original space and the inaugural time of the historical period and the world that we still inhabit, the first historical entity / identity of the current colonial / modern world-system and the entire period of modernity". In the same direction, but with a reading of the metropolitan regionalization of production of world space, we propose the idea of a "primitive transatlantic metropolization, the basis of the hierarchical relationship between European metropolises and their colonies (led by the Latin American cities)" (LEOPOLDO, 2013b, p. 4), as the geopolitical foundation of the agrarian-commercial era.

Therefore, the basic dynamic of metropolization as concentration was present from the beginning of capitalism and unfolds in other historical and geographical moments. In the urban-industrial era, which began in the eighteenth and nineteenth centuries, the direction of metropolization as concentration advanced with a continued focus on Europe, which later moved to the United States. While European and American commercial cities increasingly became industrial cities, the peripheral cities continued to feature as outlets of commercialization and the export of agricultural and mineral products.

Gradually, the peripheral cities expanded their industrialization and urbanization. In peripheral capitalism, these processes were linked to policies of concentration towards the strengthening of certain regions of the country. Peripheral metropolises were born crowned by slums, where the salaried workforce resided (expropriated from the agrarian means of production), as demanded by factories in operation and installation. The concomitant processes of industrialization and urbanization changed the way of life, the day-to-day and the social relations of production, expanding the actual capitalist processes around the world. New technologies, means of transport and communication fermented the new society-space relationship based on the urban-industrial economy.

At the end of the first half of the twentieth century, the pinnacle of urban-industrial economy was attained, with the spread of American ideals of consumption, technological advances and the growth of applied science. At that moment, on the ruins and innovations left by the end of the Second World War, an integrated concept of metropolitan space emerged: the Metropolitan Region of New York designed by Robert Moses in an interconnected manner, according to Harvey (1989).

The transition from the predominance of the urban-industrial economy to the metropolitan-financial economy is limited to the period between the concrete emergence of the metropolitan capitalist space in the USA in the middle of last century to the metropolitan deconcentration policies in the peripheral countries in the 1970s and 1980s. Deregulation of the financial sphere and neoliberal policies mobilized new strategies of capital by way of the metropolization of space.

Metropolization as a policy of space established new determinations in all areas of reproduction of the social relations of production. The financial sphere became more dense and productive and restructuring mobilized new technologies and inputs, affecting the structures of the production of value. At the same time, information in the media boosted forms of alienation. In this tempo, the doors were opened to the metropolitan-financial era and its new contradictions of space. 


\section{SPACE IN TRANSITION: NETWORK, CONNECTION AND INTEGRATION}

In the metropolitan-financial era, the metamorphoses in all spheres of life resonated with intensity in lifestyles, the production of the ecumene and human communication. The forms of production of society and space are modified intensively. The integration, connection and the network start to define the simultaneity of contemporary social relations and new concrete and abstract composition of space.

The way the subway system is organized and installed in metropolitan areas illustrates the different ways in which integration, connection and network are established. The world's first subway system dates from 1863, in operation in the metropolis of London and was then extended to the metropolitan area and other English cities. At that time, the subway system illuminated the metropolitan space. However, as we have seen, metropolitan space only specifically comes to light after the war with the integrated design of the Metropolitan Region of New York, later consolidating as a social and productive condition beyond the urban space.

If metropolitan space is conceived from the establishment and expansion of the metropolis, or "mother-city", it can be inferred that it was present-absent in some way in other historical moments, such as in Greek "urban network". However, it was only in the second half of the nineteenth century that the subway system announced metropolitan space as a real and Utopian need of the emergence of a new world and a new order. However, it is in New York's "integrated metropolitan planning" that, almost a century later, metropolitan space achieved its most radical contours.

The international adoption and incorporation of the subway network, or better the "integrated metropolitan transport network" produced some of the conditions required for the global expansion of metropolization. The network introduced the convergent reticular structure, which allowed dialogue between distant places. Lines and nodes are established from the core network and are linked with all the close and remote locations. The social network covers a wider range. Thus, advanced polycentricity and extended reproduction of the metropolis becomes possible, that is, the production of metropolitan space.

In this fashion, the network allows the urban agglomeration to reach another level: the metropolitan region. The agglomeration is transformed into a network, which finds resolution in the convergence of a meeting of cities. Several integrated agglomerations produce a metropolitan network. To the extent that the metropolitan web advances on cities, centralities and neighboring and distant spaces, expanding the network, the metropolis transforms itself into and for itself. The metropolitan web is a contradictory unit of urban fabrics.

In this dynamic, integration acts in the movement of articulation of the spaces, fostering links and adhesion to the logic of the metropolis and the metropolitan web. As in the subway system, where each station integrates certain places into the metropolitan web, integration is the combination of spaces in a serial manner.

Integration enables the necessary conjunction between spaces, centralities and cities, linked to the logic of the metropolis and conditions the production of metropolitan space. Integration is both effective on a simple scale, as in the case of the Metropolitan Region of Fortaleza, and on a complex scale, such as the São Paulo city-region. In the first situation, integration is constituted as a "network of centralities" (LEOPOLDO, 2013a) and in the second, as a network of metropolitan regions. Thus, we can speak of complex metropolitan integration and simple metropolitan integration.

In this way, the meeting refuses itself and takes place as a reunited integration. This is a particular moment determined by the transition of the urban form to the metropolitan form. Integration as a unit of agglutinating moments of urban spaces to a metropolitan whole indicates spatial connections. In the subway system, some integrated stations allow connections to other lines in the network. Each connection allows shortcuts, detours, meetings, and paths. Possible meetings multiply with the new connections in all the directions of the metropolitan space, which goes beyond the metropolitan 
region established by the State. The metropolitan space is the contradictory simultaneity of social relations of production integrated in a network via territorial connections.

By integration and connection the various latitudes and longitudes of the metropolitan space are linked in the network. The spatial and temporal links with the new technologies of communication and transport on a the worldwide level, financial globalization and the formation of the global market fertilize a universal metropolitan network by means of the international integration and connection of the logic and processes of metropolises and metropolitan webs. In this measure, Sassen (1996, p. 212) says that

in fact, economic globalization extends beyond the borders of the nation-state. This is particularly evident in key economic sectors. The current systems of governance and accountability for transnational economic activities and the actors are very disorderly when it comes to these industries. Global markets in finance and advanced services operate in part through an umbrella of "regulation" that is not centered on the state, but is centered on the market. The new geography of centrality is transnational.

Therefore, the new geography of metropolitan spaces is transnational, but also national and regional. Integrations and connections in networks occur on all geographic scales with different intensities between the metropolises and their metropolitan spaces. The metropolitan-financial economy illuminates new opportunities on the global level, but also in the articulations and specificities on and with national and regional levels.

Understanding the relationship between the metropolitan and the financial in the twenty-first century as a socio-spatial process is a major challenge. In fact, the metropolitan-financial economy is not found everywhere with the same intensity. However, if its presence apparently has not materialized, it will be a final determination, in a virtual manner.

More and more people live in metropolitan regions, which concentrate the world's main economic activities. In 1990, there were 10 metropolitan regions with more than 10 million people, and today, this number has almost tripled to 28 with 453 million people (UN, 2014). These are the major financial centers that impose the new logic of capital accumulation. The metropolization movement combines with the dynamics of financialization.

The metropolises of space and the financialization of the economy pave the way for a new world settled by integration, arranged in connections and cleaved by the network. This space-time dominated by the metropolitan-financial economy has at its heart the marks of the urban-industrial economy and agrarian-commercial economy, constituting an intense, scattered and fragmented simultaneity.

\section{FINAL CONSIDERATIONS}

Each era affirms a specific and dominant space-time. In the agrarian-commercial era, an agrarian space-time dominated; in the urban-industrial era, urban space-time. In turn, in the metropolitan-financial era, the metropolitan space-time predominates.

The metropolitan-financial era shows spatial simultaneity as simultaneity in a network, which requires integration and connection. So, the urban center disperses, gaining ground beyond the territorial limits of the city, then polycentricity emerges. Ultimately, thinking in terms of the "network of global cities" (SASSEN, 1996) or a "network of global city-regions" (SCOTT; AGNEW, SOJA; STORPER, 2001), we can speak of a transcentrality. Therefore, the creative destruction of centralities, the intense construction of policentralities, the creation of global metropolises in networks (transcentrality) and the worldwide expansion of metropolitan content is the ongoing challenge of the metropolization of space. 
Global urbanization has reached its ultimate consequences. Its adventures will still be widely experienced in human geography and history. However, we now live under the predominance of metropolization as a determining process of the reproduction of social relations. Thus, Urban Geography must seek to understand the theoretical and practical meanings of this new world and to cooperate in the rediscovery of the present and future of the metropolitan society in genesis.

\section{ACKNOWLEDGEMENTS}

To Prof. Dr. Sandra Lencioni for her permanent intellectual guidance and Prof. Dr. Wayne Davies for his grounded propositional criticism. To The National Council for Scientific and Technological Development (CNPq) for the scholarship.

\section{BIBLIOGRAPHIC REFERENCE}

AMORA, Zenilde Baima. O espaço urbano cearense: breves considerações. In: AMORA, Z. B. (orgs.). O Ceará: enfoques geográficos. Fortaleza: FUNECE, 1999.

CASTELLS, Manuel. Materials for an exploratory theory of the network society. British Journal of Sociology, $\mathrm{n}^{\mathrm{o}}$ 51, 2000.

DANTAS, Eustógio Wanderley Correia. Maritimidade nos Trópicos: por uma geografia do litoral. Fortaleza: Edições UFC, 2009.

GOTTMANN, Jean. Megalopolis or the Urbanization of the Northeastern Seaboard. Economic Geography, vol. 33, no 3, 1957.

HARVEY, David. The Condition of Postmodernity: an inquiry into the origins of cultural change. New York: Blackwell, 1989.

HARVEY, David. The Enigma of Capital: and the crises of capitalism. New York: Oxford, 2010.

LEFEBVRE, Henri. La revolución urbana. São Paulo: Alianza, 1972.

LEFEBVRE, Henri. O direito à cidade. [1ª ed., 1968]. São Paulo: Centauro, 2001.

LENCIONI, Sandra. Da Cidade e sua Região à Cidade-região. In: SILVA, José Bozarcchiello; LIMA, Luiz; ELIAS, Denise (orgs.). Panorama da Geografia Brasileira I. São Paulo: Annablume, 2006.

LEOPOLDO, Eudes. From urbanisation to metropolisation: new concepts and questions open to Urban Geography. In: MIERZEJEWSKA, Lidia; PARYSEK, Jerzy. (orgs.). Cities in a Complex World: problems, challenges and prospects. Poznan: Bogucki Wydawnictwo Naukowe, 2014a.

LEOPOLDO, Eudes. A Metropolização como Negócio: conceitos e determinações emergentes do processo de transição da urbanização à metropolização. In: VI CIETA - Congresso Iberoamericano de Estudios Territoriales y Ambientales, 2014, São Paulo. Anais do VI CIETA - Congresso Iberoamericano de Estudios Territoriales y Ambientales, São Paulo, 2014b.

LEOPOLDO, Eudes. Metropolização Litorânea: produção dos espaços dos lazeres e mercado imobiliário. Dissertação (Mestrado em Geografia). Programa de Pós-Graduação em Geografia, Universidade Estadual do Ceará, Fortaleza, 2013a.

LEOPOLDO, Eudes. A Metropolização Latino-americana: dinâmicas urbanas e redes de cidades no limiar do século XXI. In: Anais do XIV EGAL - Encuentro de Geógrafos de América Latina, Lima, 2013b.

MARX, Karl. O Capital: crítica da economia política. Vol. I. [1 $1^{\mathrm{a}}$ ed., 1867]. 2. ed. São Paulo: Nova Cultural, 1985.

ONU. World Urbanization Prospects: the 2014 revision. New York, 2014.

PEREIRA, Paulo César Xavier. São Paulo: globalización y transición metropolitana. Diez años de cambios en el Mundo, en la Geografía y en las Ciencias Sociales, 1999-2008. Actas del X Coloquio Internacional de Geocrítica, Universidad de Barcelona, 2008. 
QUIJANO, Aníbal. Dom Quixote e os moinhos de vento na América Latina. Estudos Avançados, vol. 19, $\mathrm{n}^{\circ} 55,2005$.

SANTOS, Milton. A Urbanização Brasileira. São Paulo: Hucitec, 1993.

SANTOS, Milton. La Naturaleza del Espacio: técnica y tiempo, razón y emoción. [1ª ed., 1996]. Barcelona: Ariel, 2000.

SASSEN, Saskia. Whose city is it? globalization and the formation of new claims. Public Culture, n. 8, 1996. SCOTT, Allen; AGNEW, John; SOJA, Edward; STORPER, Michael. Cidades-regiões globais. Espaço \& Debates, $n^{\circ} 41,2001$.

SILVA, José Bozarcchiello da. Quando os incomodados não se retiram: uma análise dos movimentos sociais em Fortaleza. Fortaleza: Multigraf Editora, 1992.

Submitted 6 june 2016

Accepted 8 july 2016 